\title{
Drought Stress Affecting Growth and Some Physiological Characters of Three Cocoa Clones at Seedling Phase
}

\author{
Fakhrusy Zakariyya ${ }^{1 *)}$ and Didik Indradewa ${ }^{2}$ \\ ${ }^{1 *}$ Indonesian Coffee and Cocoa Research Institute, Jl. PB. Sudirman 90, Jember, Indonesia \\ ${ }^{2}$ Faculty of Agriculture, University of Gadjah Mada, Bulaksumur, Caturtunggal, \\ Kec. Depok, Kabupaten Sleman, Daerah Istimewa Yogyakarta \\ ${ }^{*}$ Corresponding author: fakhrusy.zakariyya@gmail.com \\ Received: 4 September 2018 / Accepted: November 2018
}

\begin{abstract}
Drought stress can have substantial negative impacts on cocoa plant growth until affect the death of plant. The present study aimed to determine the effect of drought stress on the some physiological characters of cacao (Theobroma cacao L.) seedlings. The research was carried out at the Indonesian Coffee and Cocoa Research Institute, Jember, East Java, Indonesia. This research was conducted from January-December 2017. The experiment was designed by using completely randomized block design with two factors and with three replications. The first factor was clones, namely ICS 60, Sulawesi 1 and KW 641 clones. The second factor was interval of watering treatment, namely watering every 2 days (control/ adequate water condition), watering every 5 days (moderate stress), and watering every 8 days (severe stress). Result of this study concluded that drought stress reduced the growth of cocoa seedlings, mainly as a result of reducing photosynthetic activities in all stressed cocoa clone seedlings. Under drought stress, KW 641 and Sulawesi 1 had higher leaf area, chlorophyll a, chlorophyll b, total chlorophyll content, relative water content, and photosynthetic rate than ICS 60 clone.
\end{abstract}

Keywords: Growth, drought stress, photosynthetis, Theobroma cacao L.

\section{INTRODUCTION}

Cocoa (Theobroma cacao) is a most important plantation crop in the world. The bean produced are for the production of chocolates and confectionaries. However, cocoa production is highly sensitive with the changes of weather condition (Santosa et al., 2018). Ideally, cocoa requires a minimum $1500-2000 \mathrm{~mm}$ of rainfall with less than 3 months of dry season (Baon, 1988). However, ENSO (El Nino Southern Oscillation) cause prolonged dry season in the past decade and lead to occur abiotic stress. Abiotic stress, especially drought stress that related to El Nino phenomenon, is noted that can decrease global cocoa production up to $15 \%$ (ICCO, 2010). In Sulawesi, it was found that ENSO-related drought caused a $62 \%$ loss of cocoa production (Keil et al., 2008). Furthermore, Gateau-Rey et al. (2018) explained that drought stress can have substantial negative impacts on plant growth until the death of plant up to $15 \%$.

The detrimental effects of drought stress on the growth and yield of cocoa are well documented (Gateau-Rey et al., 2018; Keil et al., 2008; Schroth et al., 2016). It is therefore of great importance not only to know growth and yield of cocoa, but also to understand the process of physiological 
level in this stress. Under drought stress, Medeiros et al. (2012) reported that the inflow of water reduces due low water availability in soil, which potentially affects the physiological processes dependent on turgor pressure because of low water status in plant. To know plant water status, relative water content (RWC) is important variable that commonly studied to assess plant physiological responses to water stress (Silva et al., 2009; Marchese et al., 2010; Silva et al., 2010; Medeiros et al., 2012). Moreover, this adverse condition will inhibit physiological process and then decrease the yield of cocoa.

Plant generally has mechanism to minimize water loss during stress condition. Stomatal closure is a strategy of cocoa plant for diminishing water loss through transpiration process by regulating stomatal conductance (Zakariyya et al., 2016). Stomatal conductance can be defined as the ability of stomata that plays a role on $\mathrm{CO}_{2}$ uptake and water loss through transpiration. That was determined by the degree of stomatal aperture and therefore the physical resistances to the movement of gases between the air and the interior of the leaf (Pietragalla \& Pask, 2012). In other hand, stomatal closure also consequently reduces $\mathrm{CO}_{2}$ uptake.

Drought stress also inhibit the activity of enzymes, such as nitrate reductase (Mandi et al., 2018). Then, it also causes the degradation of photosynthetic pigment, such as chlorophyll. The degradation in the concentration of photosynthetic pigments causes damage in photochemical activity. Chlorophyll, water and $\mathrm{CO}_{2}$ are main components for photosynthesis process and then inhibit plant growth. Measuring physiological character, especially chlorophyll, photosynthesis, and gas exchange is an effective approach to understand effect of water stress on growth and production, because this character is highly correlated with yield of cocoa (Zakariyya et al., 2015; Anita-sari et al., 2015). In other case, physiological traits for drought tolerance were evaluated in a recent study to identify the potential of certain traits to be used as a way to accelerate breeding during early screening (Alban et al., 2016). The present study aimed to determine the effect of drought stress on the growth and some physiological charater of cacao (Theobroma cacao L.) seedlings.

\section{MATERIALS AND METHODS}

The research was carried out at the glasshouse of Indonesian Coffee and Cocoa Research Institute (ICCRI), Jember, East Java, Indonesia. This research was conducted from January-December 2017. The relative humidity and average temperature during the experiment are measured during experiment period. The relative humidity ranged between 76 and $97 \%$ and temperature between 26.9 and $28.5^{\circ} \mathrm{C}$. Three cocoa scions, viz. ICS 60 , Sulawesi 1, and KW 641 was grafted on to Scavina 6 halfsibs clone as a rootstock. Plant were grafted 5 months after sowing by using top grafting technique. Each polybag was fulfilled with $12 \mathrm{~kg}$ soil with a density of $1.1 \mathrm{~g} \mathrm{~cm}^{-3}$.

The experiment was designed by using completely randomized block design with three replications. The first factor was clones, i.e. ICS 60, Sulawesi 1 and KW 641 clones. The second factor was interval of watering treatment, i.e., watering every 2 days (control/ no stress), watering every 5 days (moderate stress), and watering every 8 days (severe stress). Some variables of growth component that were measured include plant height, stem diameter, and leaf area. Plant height was measured by using ruler. Stem diameter was measured by using caliper. Leaf area meter was measured by using leaf area meter. Plant height, stem diameter, and leaf area was measured on 80 days after treatment. Photosynthesis rate, stomatal conduction, 
transpiration rate, leaf temperature, and intercelullar $\mathrm{CO}_{2}$ of cocoa seedlings was measured with a portable photosynthesis system analyzer Li-Cor 6400 (Licor Inc Lincoln Ne USA). For this measurment, the equipment was tagged on the youngest fully expanded leaf which are reported to be the most physiologically active.

Chlorophyll content was tested by using spectrophotometric method on 80 days after treatment. 0.1 gram of leaf was pulverized by using mortar and then extracted with $50 \mathrm{~mL}$ acetone $80 \%$. The sample then was filtered by using filter paper in Erlenmeyer glass. The extract was put into cuvvet to measure the absorbance with spectrophotometer (varian cary model 50 conc) at $663 \mathrm{~nm}$ and $646 \mathrm{~nm}$ wavelength. As blank was used acetone $80 \%$. Chlorophyll content was determined as follows : Chlorophyll $\mathrm{a}=12.21 \mathrm{x}$ A663-2.81 x A646 x 50; Chlorophyll b= $20.13 \times$ A646-5.03 x A663 x 50; and total chlorophyll content $=$ chlorophyll $\mathrm{a}+$ chlorophyll b.

The activity of nitrate reductation was analyzed by using spectrophotometric method. 0.2 gr leaf was cut slightly. Dark movie tube was prepared and added with $5 \mathrm{~mL} 0.1 \mathrm{M}$ phospate buffer ( $\mathrm{pH} 7)$. The cut leaf was put into tube that had been added with buffer phospate and waited for 24 hours. After 24 hours of immersion, it was replaced with new buffer solution and added $0.1 \mathrm{~mL} \mathrm{NaNO}_{3} 5 \mathrm{M}$ as substrat, then incubated for 2 hours. In the same time, Dye reagent consisted of $0.2 \mathrm{~mL}$ of $1 \%$ sulphanilamide in $3 \mathrm{~N} \mathrm{HCl}$ and $0.2 \mathrm{~mL} 0.02 \%$ $\mathrm{N}$-Naphtylethylene diamine was prepared in a test tube. After incubation for 2 hours, $0.1 \mathrm{~mL}$ of filtrate was taken from a dark movie tube and put into the test tube containing the dye reagent, and then wait until it was a pink as a sign to reducing nitrate to nitrite by nitrate reductase enzyme. One test tube is not given the filtrate and used as a blank. After the change of color added $2.5 \mathrm{~mL}$ of distilled water, and moved in the cuvvette of spectrophotometer, and the observed absorbance at a wavelength of $540 \mathrm{~nm}$. Correlation and regression analysis was conducted to determine the relationship among of variables. Data were analyzed using analysis of variance, if there is a significant difference then it is continued with Tukey test at 5\% level.

\section{RESULTS AND DISCUSSION}

Cocoa growth was represented in Table 1. Watering interval treatment was affected in plant height, stem diameter, and leaf area variables. The increasing of watering interval from 2 days to 5 days significantly reduced only leaf area, but the increasing of watering interval from 2 days to 8 days reduced all growth parameters. The difference in plant height, stem diameter, and leaf area between regularly watering and severe drought stress (watering every 8 days) seedlings was about $10.17 \%, 10.19 \%$, and $25.63 \%$, respectively. This was similar with the study of Chibuike \& Daymond (2015) that reported there was a significant decrease, approximately more than $10 \%$ of reduction, in plant height with the increasing of watering interval treatment. In addition, Lahive et al. (2018) also showed that leaf area and stem diameter declined up to $20 \%$ in response to water deficit. Therefore, it be concluded that drought stress was significantly induced the reduction of vegetative stage in cocoa.

The activity of some enzymes of plant metabolic pathway was regulated by water (Lisar et al., 2012). Nitrate reductase is one of the many enzymes that sensitive to water stress (Fresneau et al., 2007). This enzyme plays role in catalyzing nitrate to be nitrite. This enzyme is the regulator of nitrogen assimilation in cocoa plant (Armendariz et al., 1991). According to Table 2., the activity of nitrate reductase was affected by watering 
interval treatment. Watering interval every 5 days (moderate drought stress) and every 8 days (severe drought stress) relatively decreased this enzyme activity by $46.98 \%$ and $61.57 \%$ than that watering every 2 days. The result proved that more severe drought stress level, the lower the activity of nitrate reductase. Several studies also showed that drought can decrease this enzyme activity (Ananthi \& Vijayaraghavan, 2012; Chachar et al., 2016; Mutjaba et al., 2016; Mandi et al., 2018). Under drought stress, Hernandez-Cruz et al. (2015) stated that a decrease in nitrate reductase activity was caused by the low nitrogen status in plant, especially nitrate compound. Santos et al. (2014) represented that soil water deficit significantly reduced leaf nitrogen content for all cocoa genotypes. Furthermore, Siswanti \& Agustin (2014) stated that how drought stress can decrease this enzyme activity because water was useful to donate the proton and electron for the activity of nitrate reductase, spesifically, in each changes of nitrate to be nitrite process, water had to donate six electron for its process. The reduction of nitrate is mediated by nitrate reductase to generate nitrite. Nitrite is converted to be amonium through nitrate reductase. In other hand, nitrate reductase plays a role to synthesize nitrate oxide, which it is a molecule that is recognized as a signal transduction in plant.
Tabel 2 also demonstrated that watering interval treatment influenced on chlorophyll a content, chlorophyll b content, and total chlorophyll content. Watering every 8 days could decrease chlorophyll a content, chlorophyll b content, and total chlorophyll content until $42.89 \%, 63.39 \%$, dan $53.57 \%$, respectively, than regularly watering (every 2 days). In addition, chlorophyll a and total chlorophyll was also affected by clones. ICS 60 clone had lower chlorophyll a and total chlorophyll content than both KW 641 and Sulawesi 1 clones. More decrease in ICS 60 clone indicated that it is more sensitive to water deficit than KW 641 and Sulawesi 1 clones.

A decrease of chlorophyll content is a generally observed phenomenon under this stress. Prihastanti (2010) also reported the cocoa that grown on low soil water content have chlorophyll $\mathrm{a}$ and $\mathrm{b}$ are lower than those grown on adequate soil water content. Chlorophyll a is the most generally used the pigment of photosynthetic and it absorbs blue, red and violet wavelengths in the visible spectrum. It is also involved in oxygenic photosynthesis that oxygen is the main product of that process. In another side, chlorophyll $\mathrm{b}$ absorbs blue light and is used to extend the range of light wavelength. Chlorophyll a and b work simultaneously to absorb blue to red spectrum of light.

Tabel 1. Plant height $(\mathrm{cm})$, stem diameter $(\mathrm{mm})$, and leaf area $\left(\mathrm{cm}^{2}\right)$ of three cocoa clones at different watering interval treatment

\begin{tabular}{|c|c|c|c|}
\hline Watering interval (days) & Plant height & Stem diameter & Leaf area \\
\hline 2 (normal) & $74.02 \mathrm{a}$ & $11.97 \mathrm{a}$ & $2273.48 \mathrm{a}$ \\
\hline 5 (moderate stress) & $69.61 \mathrm{ab}$ & $11.43 \mathrm{a}$ & $1803.86 \mathrm{~b}$ \\
\hline 8 (severe stress) & $66.49 \mathrm{~b}$ & $10.75 \mathrm{~b}$ & $1690.61 \mathrm{~b}$ \\
\hline \multicolumn{4}{|l|}{ Clones } \\
\hline ICS 60 & $68.99 \mathrm{p}$ & $11.30 \mathrm{p}$ & $1645.53 \mathrm{p}$ \\
\hline KW 641 & $70.39 \mathrm{p}$ & $11.23 \mathrm{p}$ & $2034.45 \mathrm{q}$ \\
\hline Sulawesi 1 & $70.74 \mathrm{p}$ & $11.62 \mathrm{p}$ & $2087.98 \mathrm{q}$ \\
\hline Interactions & $(-)$ & $(-)$ & $(-)$ \\
\hline
\end{tabular}


Tanaka \& Tanaka (2005) has been demonstrated that chlorophyll $\mathrm{b}$ is synthesized from chlorophyll a through enzyme activity, and it was highly correlated with soil water availability. Lisar et al. (2012) stated that water stress inhibits the synthesis of chlorophyll through several stages namely (a) the synthesis of 5-Aminole-Vuliniuc Acid (ALA). (b) the condensation of this compound into porphobilinogen and primary tetrapyrrol, that is transformed into protochlorophyllide; (c) light-dependent conversion of protochlorophyllide into chlorophyllide; and (d) chlorophylls $\mathrm{a}$ and $\mathrm{b}$ synthesis along with their inclusion into developing pigmentprotein complexes of the photosynthetic apparatus. In other case, under drought stress, chlorophyll pigment was also degradated by the existence of ROS due to oxidative stress (Rogers \& Munne-Bosch, 2016).

Cacao leaf water content are used to be an indicator of plant water status. The relative water content also strongly correlated with water potential in plant tissue (Gholami et al., 2012). Table 3 informed that relative water content was affected by the interaction between clones and watering interval treatment. Under normal condition (watering every 2 days), there were no significant differences in all clones. Watering every 5 days significantly decreased relative water content in ICS 60 clones up to $13.73 \%$ than watering every 2 days. Meanwhile, the increasing of watering interval from 2 days to 8 days induced the reduction of relative water content in all clones. It indicated that in moderate drought stress level, ICS 60 clone had low plant water status than others.

In young cocoa that was grown under similar environmental conditions, leaf water potential were significantly reduced when watering was withheld for 10 days (Bae et al., 2008). Moreover, Almeida et al. (2016) reported that water deficit stress resulted in reduced leaf water potential and relative water content (RWC) with the former being a more sensitive indicator of plant water status. The results of Balasimha et al. (2013) trials indicated that the genotypes showing higher water potential can be considered as drought tolerant. The decreasing of RWC in leaf under drought stress may depend on the reduction of plant vigor. Blokina et al. (2003) stated that under drought stress, cell membrane subjects to changes such as penetrability and decrease in sustainability. Arjenaki et al. (2012) reported that microscopic observation of dehydrated cells, revealed damages including cleavage in the membrane and sedimentation of cytoplasm content.

Tabel 2. The activity of nitrate reductase, chlorophyll a, chlorophyll b, and total chlorophyll content of three cocoa clones at different watering interval treatments

\begin{tabular}{|c|c|c|c|c|}
\hline Watering interval (days) & $\begin{array}{c}\text { Nitrate reductase } \\
\text { activity }\end{array}$ & $\begin{array}{c}\text { Chlorophyll a } \\
\text { content }\end{array}$ & $\begin{array}{c}\text { Chlorophyll b } \\
\text { content }\end{array}$ & $\begin{array}{c}\text { Total chlorophyll } \\
\text { content }\end{array}$ \\
\hline 2 (normal condition) & $2.81 \mathrm{a}$ & $18.09 \mathrm{a}$ & $19.31 \mathrm{a}$ & $37.39 \mathrm{a}$ \\
\hline 5 (moderate stress) & $1.49 \mathrm{~b}$ & $15.88 \mathrm{a}$ & $14.90 \mathrm{a}$ & $30.77 \mathrm{~b}$ \\
\hline 8 (severe stress) & $1.08 \mathrm{~b}$ & $10.33 \mathrm{~b}$ & $7.04 \mathrm{~b}$ & $17.36 \mathrm{~b}$ \\
\hline \multicolumn{5}{|l|}{ Clones } \\
\hline ICS 60 & $1.53 \mathrm{p}$ & $12.35 \mathrm{p}$ & $11.23 \mathrm{p}$ & $24.18 \mathrm{p}$ \\
\hline KW 641 & $1.94 \mathrm{p}$ & $16.39 \mathrm{q}$ & $15.30 \mathrm{p}$ & $31.59 \mathrm{q}$ \\
\hline Sulawesi 1 & $1.91 \mathrm{p}$ & $15.56 \mathrm{q}$ & $14.72 \mathrm{p}$ & $30.37 \mathrm{q}$ \\
\hline Interactions & $(-)$ & $(-)$ & $(-)$ & $(-)$ \\
\hline
\end{tabular}


Tabel 3. Relative water content $(\%)$ of three cocoa clones at different watering interval treatments

\begin{tabular}{lcrc}
\hline \multirow{2}{*}{ Clones } & \multicolumn{2}{c}{ Watering interval (days) } \\
\cline { 2 - 4 } & 2 & 5 & $80.83 \mathrm{~d}$ \\
\hline ICS 60 & $86.63 \mathrm{a}$ & $72.90 \mathrm{bc}$ & $74.18 \mathrm{bc}$ \\
KW 641 & $86.66 \mathrm{a}$ & $81.22 \mathrm{ab}$ & $76.42 \mathrm{~b}$ \\
Sulawesi 1 & $86.31 \mathrm{a}$ & $79.45 \mathrm{ab}$ & - \\
\hline Interactions & - & $(+)$ & - \\
\hline Note : $\quad$ Values on the same column followed by the same letter were not different based on the Tukey test with $\alpha=5 \%$ &
\end{tabular}

Based on Table 4 there was no interaction between clone and watering interval treatment on stomatal conductance, transpiration rate, and intercelullar $\mathrm{CO}_{2}$ concentration. Single factor of watering interval affected on that variables. Watering every 8 days could reduce stomatal conductance, transpiration rate and intercelullar $\mathrm{CO}_{2}$ concentration. Spesifically, severe drought stress caused the reduction of stomatal conductance, transpiration rate, and intercelullar $\mathrm{CO}_{2}$ concentration than that in normal condition. It described that the severe drought stress level would simultaneously reduce the activity of stomata and gas exhange. In other hand, single factor of clone affected on stomatal conductance and transpiration rate. Sulawesi 1 and KW 641 has lower both stomatal conductance and transpiration rate than ICS 60 .

The various in stress severity was reffered to the response of stomatal and gas exchange between clones. This study were reported by Balasimha et al. (2013), who concluded that effective stomatal regulation is a key drought tolerance response of cacao that can result in decreased transpirational water loss. The ability of crops to maintain water potential values and turgor under water-limiting conditions is an important physiological adaptation towards periods of reduced water availability. Drought stress implicated to stomatal closure and then could decrease $\mathrm{CO}_{2}$ diffusion from the atmosphere.

Table 5 showed that photosynthetic rate was influenced by interaction between treatments. In normal condition, or 2 days of watering interval, photosynthetic rate in all clones was not significant different. The decreasing of photosynthetic rate was accompanied by the increasing of watering interval. Watering every 5 days and 8 days declined photosynthetic rate in all clones. In severe drought stress, watering every 8 days, ICS 60 was the most suffering clone in decline of photosynthetic rate than KW 641 and Sulawesi 1 clones. Similar to Alban et al. (2016) that cocoa photosynthetic rate drastically declined accompanied with an increase of water stress severity.

The limitation of photosynthetic processes under drought stress is caused in consecutive ways, i.e. (a) qualitative and quantitative degradation in photosynthesizing pigments, especially chlorophyll, (b) the reduction of $\mathrm{CO}_{2}$ uptake due to stomatal closure, and (c) low water compound because water resourches in soil and plant is limited. It was showed in Table 6. That photosynthesis rate has positive correlation with chlorophyll content, relative water content, and intercelullar $\mathrm{CO}_{2}$ concentration. It proved that the increasing of one component will influenced in the increasing another component. In other case, photosynthesis had strongly correlation with plant height. It implied that plant height would be higher if photosynthetic rate was higher.

The foliar photosynthetic rate of higher plants is known to decrease as the relative water content (RWC) and leaf water potential decrease. However, the discussion about water deficit mainly limits photosynthesis 
Tabel 4. Stomatal conductance $\left(\mathrm{mmol} \cdot \mathrm{m}^{-2} \cdot \mathrm{s}^{-1}\right)$, transpiration rate $\left(\mathrm{mmol} \mathrm{H} \mathrm{H}_{2} \mathrm{O} \cdot \mathrm{m}^{2} \cdot \mathrm{s}^{-1}\right)$, and intercelullar $\mathrm{CO}_{2}$ $\left(\mathrm{mmol} \mathrm{CO} \mathrm{C}_{2}\right)$ concentration of three cocoa clones at different watering interval treatment

\begin{tabular}{lccc}
\hline Watering interval (days) & Stomatal conductance & Transpiration rate & $\begin{array}{c}\text { Intercelullar } \mathrm{CO}_{2} \\
\text { concentration }\end{array}$ \\
\hline 2 (normal) & $0.48 \mathrm{a}$ & $6.02 \mathrm{a}$ & $343.90 \mathrm{a}$ \\
5 (moderate stress) & $0.38 \mathrm{a}$ & $4.39 \mathrm{~b}$ & $346.75 \mathrm{a}$ \\
8 (severe stress) & $0.12 \mathrm{~b}$ & $1.78 \mathrm{c}$ & $227.33 \mathrm{~b}$ \\
Clones & $0.41 \mathrm{p}$ & $4.72 \mathrm{p}$ & $317.67 \mathrm{p}$ \\
ICS 60 & $0.29 \mathrm{q}$ & $3.74 \mathrm{q}$ & $299.13 \mathrm{p}$ \\
KW 641 & $0.28 \mathrm{q}$ & $3.72 \mathrm{q}$ & $301.18 \mathrm{p}$ \\
Sulawesi 1 & $(-)$ & $(-)$ & $(-)$ \\
\hline Interactions & & \\
Note: Values on the same column followed by the same letter were not different based on the Tukey test with $\alpha=5 \%$.
\end{tabular}

Tabel 5. Photosynthetic rate $\left(\mu \mathrm{mol} \mathrm{CO}_{2} \cdot \mathrm{m}^{-2} \cdot \mathrm{s}^{-1}\right)$ of three cocoa clones at different watering interval treatment

\begin{tabular}{lccc}
\hline \multirow{2}{*}{ Clones } & \multicolumn{3}{c}{ Watering interval (days) } \\
\cline { 2 - 3 } & 2 & 5 & 8 \\
\hline ICS 60 & $12.43 \mathrm{a}$ & $6.32 \mathrm{bc}$ & $5.46 \mathrm{c}$ \\
KW 641 & $12.30 \mathrm{a}$ & $9.24 \mathrm{~b}$ & $8.53 \mathrm{~b}$ \\
Sulawesi 1 & $12.30 \mathrm{a}$ & $9.28 \mathrm{~b}$ & $(+56 \mathrm{~b}$ \\
Interaction & & $(+)$ \\
\hline Note : Values on the same column followed by the same letter were not different based on the Tukey test with $\alpha=5 \%$. $(+)$ :
\end{tabular}

Table 6. Correlation analysis of among variables

\begin{tabular}{|c|c|c|c|c|c|c|c|c|c|c|c|}
\hline & Chla & ChlB & ChlT & $\mathrm{Pn}$ & $\mathrm{gS}$ & $\mathrm{Ci}$ & $\mathrm{E}$ & RWC & LA & $\mathrm{PH}$ & SD \\
\hline NR & $0.64 *$ & $0.71 *$ & $0.69 *$ & $0.62 *$ & 0.39 ns & $0.48 *$ & 0.43 ns & $0.65 *$ & $0.54 *$ & $0.65 *$ & 0.39 ns \\
\hline Chl a & & $0.96 *$ & $0.98 *$ & $0.68 *$ & $0.53 *$ & $0.65 *$ & $0.56 *$ & $0.75 *$ & $0.65 *$ & $0.41^{\text {ns }}$ & $0.37^{\mathrm{ns}}$ \\
\hline Chl b & & & $0.98 *$ & $0.68 *$ & $0.59 *$ & $0.66 *$ & $0.61 *$ & $0.73 *$ & $0.60 *$ & $0.44^{\text {ns }}$ & $0.42 \mathrm{~ns}$ \\
\hline ChlT & & & & $0.69 *$ & $0.57 *$ & $0.66 *$ & $0.60 *$ & $0.74 *$ & $0.62 *$ & $0.47 *$ & $0.40^{\mathrm{ns}}$ \\
\hline Pn & & & & & $0.46 *$ & $0.38^{\mathrm{ns}}$ & $0.57 *$ & $0.81 *$ & $0.88 *$ & $0.58 *$ & $0.38^{\mathrm{ns}}$ \\
\hline $\mathrm{gS}$ & & & & & & $0.83 *$ & $0.95 *$ & $0.47 *$ & $0.26^{\mathrm{ns}}$ & $0.31^{\text {ns }}$ & $0.52 *$ \\
\hline $\mathrm{Ci}$ & & & & & & & $0.84 *$ & $0.51 *$ & $0.29 \mathrm{~ns}$ & $0.42^{\text {ns }}$ & $0.45 *$ \\
\hline $\mathrm{E}$ & & & & & & & & $0.54 *$ & $0.38^{\mathrm{ns}}$ & $0.41^{\mathrm{ns}}$ & $0.49 *$ \\
\hline RWC & & & & & & & & & $0.83 *$ & $0.45 *$ & $0.41^{\mathrm{ns}}$ \\
\hline LA & & & & & & & & & & $0.60 *$ & $0.38^{\mathrm{ns}}$ \\
\hline PH & & & & & & & & & & & $0.26^{\mathrm{ns}}$ \\
\hline
\end{tabular}

through stomatal closure or through metabolic impairment. Photosynthesis consist of two processes, namely light reaction and dark reaction. In a light reaction that is the reaction of light energy capture. The light energy is absorbed by the thylakoid membrane and raise low-energy electrons from water molecule. The electrons move from chlorophyll a to the electron transport system that produces ATP (from ADP + P). These electrons are also captured by $\mathrm{NADP}^{+}$. After receiving electrons, $\mathrm{NADP}^{+}$immediately changes to NADPH. These molecules (ATP and NADPH) temporarily store energy in the form of energy electrons that will be used to reduce $\mathrm{CO}_{2}$. The second process of photosynthesis is dark reaction. Dark reaction is also known as Calvin cycle. In this reaction, $\mathrm{CO}_{2}$ is converted to gliseraldehide-3phospate. In one cycle of Calvin cycle, plant will generate 1 molecule of G3P. Thus, plant need 2 molecules of G3P (twice of Calvin 
cycle process) to form glucose in photosynthesis system. Under drought stress, The reducing of $\mathrm{CO}_{2}$ diffusion from the air to the the site of carboxylation is generally considered the main cause for reduced photosynthesis under water stress. Early biochemical effects of water deficits that involve alterations in photophosphorylation (a decrease in the amount of ATP leading to a decreased regeneration of RuBP) and seem to be dependent on species showing different thresholds for metabolic down-regulation.

\section{CONCLUSIONS}

This study concluded that drought stress reduced the growth of cocoa seedlings, mainly as a result of reducing photosynthetic activities in all stressed cocoa clone seedlings. Under drought stress, KW 641 and Sulawesi 1 had higher leaf area, chlorophyll a, chlorophyll $b$, total chlorophyll content, relative water content, and photosynthetic rate than ICS 60 clone.

\section{ACKNOWLEDGEMENT}

Authors would like to thank to the Lembaga Pengelola Dana Pendidikan for research funding. Authors also would like to thank Mr. Herwanto who helped prepared the plant material for this research.

\section{REFERENCES}

Alban, M.B.A.K. \& S.E.A.K.B. Hebbar (2016). Morpho-physiological criteria for assessment of two month old cocoa (Theobroma cacao L.) genotypes for drought tolerance. Indian Journal Plant Physiology, 21, 23-30.

Almeida, J.D.; W. Tezzara \& A. Herrera (2016). Physiological responses to drought and experimental water deficit and waterlogging of four clones of cacao (Theobroma cacao L.) selected for cultivation in Venezuela. Agricultural Water Management, 171, 80-88.

Ananthi, K. \& H. Vijayaraghavan (2012). Soluble protein, nitrate reductase activity and yield responses in cotton genotypes under water stress. Insight Biochemistry, 2, 1-4.

Anita-Sari, I.; F. Zakariyya \& A.W. Susilo (2015). Relationship between physiological characteristic and bean quality on some cocoa (Theobroma cacao L.) clones. Pelita Perkebunan, 31, 143-151.

Arjenaki, F.G.; R. Jabbari \& A. Morshedi (2012). Evaluation of drought stress on relative water content, chlorophyll content and mineral elements of wheat (Triticum aestivum L.) varieties. International of Journal Agricultural \& Crop Science, 4, 726-729.

Armendariz, A.; S. Djojodirdjo; W. Mangoendidjojo \& H. Hartiko (1991). Aktivitas enzim nitrat reduktase dan korelasinya terhadap sifat pertumbuhan tanaman kakao (Theobroma cacao L.) muda. Ilmu Pertanian, 4, 257-311.

Bae, H.; S.H. Kim; M.S. Kim; R.C. Sicher; D. Lary; M.D. Stream; S. Narajhan \& B.A. Bailey (2008). The drought response of Theobroma cacao (cacao) and the regulation of genes involved in polyamine biosynthesis by drought and other stresses. Plant Physiology and Biochemistry, 46, 174-188.

Balasimha, D.; A.S. Elain \& C.T. Jose (2013). Genotypic variations in chlorophyll fluorescence and stomatal conductance of cocoa in relation to drought tolerance. Journal of Plant and Crops, $41,40-45$.

Bijanzadeh, E. \& Y. Emam (2010). Effect of defoliation and drought stress on yield components and chlorophyll content of wheat. Pakistan Journal of Biological Science, 13, 699-705.

Blokhina, O.; E. Virolainen \& K.V. Fagerstedt (2003). Anti-oxidative damage and oxygen deprivation stress. Annual Botany, 91, 179-194. 
Chibuike, G.U., \& A.J. Daymond (2015). Mycorrhizae inoculation did not influence the response of cocoa seedlings to water stress. American-Eurasian Journal Agriculture \& Environmental Science, 15, 944-956.

Din, J.; S.U. Khan; I. Ali \& A.R. Gurmani (2011). Physiological and agronomic response of canola varieties to drought stress. Journal Animal and Plant Science, 21, 78-82.

Fresneau, C.; J. Ghashghaie \& G. Cornic (2007). Drought effect on nitrate reductase and sucrose-phosphate synthase activities in wheat (Triticum durum L.): Role of leaf internal $\mathrm{CO}_{2}$. Journal of Experimental Botany, 58, 2983-2992.

Gateau-Rey, L.; E.V.J. Tanner; B. Rapidel; J-P. Marelli \& S. Royaert (2018). Climate change could threaten cocoa production: Effects of 2015-16 El Nino-related drought on cocoa agroforests in Bahia, Brazil. Plos ONE, 13, 1-17.

Gholami, M.; M. Rahemi \& S. Rastegar (2012). Use of rapid screening methods for detecting drought tolerant cultivars of ûg (Ficus carica L.). Scientia Horticulturae, 143, 7-14.

Hernandez-Cruz, A.E; E. Sánchez; P. Preciado-Rangel; M.L. García-Bañuelos \& A. EspinozaBanda (2015). Nitrate reductase activity, biomass, yield, and quality in cotton in response to nitrogen fertilization. International Journal of Experimental Botany, 84, 454-460.

Keil, A.; M. Zeller; A. Wida; B. Sanim \& R. Birner (2008). What determines farmers' resilience towards ENSO-related drought? An empirical assessment in Central Sulawesi, Indonesia. Climate Change, 86, 291-307.

Lahive, F.; P. Hadley \& A. Daymond (2018). The impact of elevated $\mathrm{CO}_{2}$ and water deficit stress on growth and photosynthesis of juvenile cacao (Theobroma cacao L.). Photosynthetica, 56, 911-920.

Lisar, S.Y.S.; R. Motafakkerazad; M.M. Hossain \& I.M.M. Rahman (2012). Water stress in plants: Causes, effects and responses. p. 1-14.In: WaterStress(Ed. I.M.M. Rahman). InTech, Croatia.

Mandi, S.; A.K. Pal; R. Nath \& S. Hembram (2018). ROS scavenging and nitrate reductase enzyme activity in mungbean (Vigna radiata L. Wilczek) under drought stress. International Journal Current Microbiological Applied Sciences, 7, 1031-1039.

Marchese, J.A.; J.F.S. Ferreira; V.L.G. Rehder \& O. Rodrigues (2010). Water deficit effect on the accumulation of biomass and artemisinin in annual wormwood (Artemisia annua L., Asteraceae). Brazilian Journal Plant Physiology, 22, 1-9.

Mujtaba, S.M.; S. Chachar \& Z. Chachar (2016). Physiological characterization of six wheat genotypes for drought tolerance. International Journal of Research Granthaalayah, 4, 184-196.

Medeiros, D.B.; E.C. da Silva; H.R.B. Santos; C.M. Pacheco; R.S. Musser \& R.J.M.C. Nogueira (2012). Physiological and biochemical responses to drought stress in Barbados cherry. Brazilian Journal Plant Physiology, 24, 181-192.

Mujtaba, S.M.; M.A. Khan; B.K. Khanzada; B.K.M.U.S. Khan \& S. Mumtaz (2016). Nitrate reductase activity, nitrate and relative water contents in wheat as fluctuated during $24 \mathrm{~h}$ cycle under water stress. Sky Journal of Agricultural Research, 5, 161-167.

Pietragalla, J. \& A. Pask (2012). Stomatal conductance. In Wheat. Physiological Breeding II. A Field Guide to Wheat Phenotyping. A.J.D. Pask; J. Pietragalla; D.M. Mullan \& M.P. Reynolds (Eds.). CIMMYT, Mexico.

Rogers, H. \& S. Munné-Bosch (2016). Production and scavenging of reactive oxygen species and redox signaling during leaf and flower senescence: Similar but different. Plant Physiology, 171, 1560-1568.

Santos, I.C.; A.F. Almeida; D. Anhert; A.S. Conceciao; C.P. Pirovani; J.L. Pires; R.R. Valle \& 
V.C. Balligar (2014). Molecular, physiological and biochemical responses of Theobroma cacao L. genotypes to soil water deficit. PLoS ONE, 9, 1-31.

Santosa, E.; G.P. Sakti; M.Z. Fattah; S. Zaman \& A. Wachjar (2018). Cocoa production stability in Relation to changing rainfall and temperature in East Java, Indonesia. Journal of Tropical Crop Science, 5, 6-17.

Schroth, G.; P. Läderach; A.I. Martinez-Valle; C. Bunn \& L. Jassogne (2016). Vulnerability to climate change of cocoa in West Africa: Patterns, opportunities and limits to adaptation. Science of the Total Environment, 556, 231-241.

Silva, E.C.; R.J.M.C. Nogueira; F.H.A. Vale; N.F. Melo \& F.P. Araujo (2009). Water relations and organic solutes production in four umbu tree (Spondias tuberosa) genotypes under intermittent drought. Brazilian Journal Plant Physiology, 21, 43-53.
Silva, E.C.; M.F.A. Silva; R.J.M.C. Nogueira \& M.B. Albuquerque (2010). Growth evaluation and water relations of Erythrina velutina seedlings in response to drought stress. Brazilian Journal Plant Physiology, 22, 225-233.

Siswanti, D.U. \& R.V. Agustin (2014). Respons fisiologis padi (Oryza sativa L.) "Segreng" dan "Menthik Wangi" terhadap aplikasi pupuk organik cair dan dekomposer. Jurnal Biogenesis, 2, 89-93.

Tanaka, R. \& A. Tanaka(2005). Effects of chlorophyllide a oxygenase overexpression on light acclimation in Arabidopsis thaliana. Photosynthesis Research, 85, 327-340.

Zakariyya, F.; B. Setiyawan \& A.W. Susilo (2016). Stomatal, proline, and leaf water status characters of some cocoa clones (Theobroma cacao L.) on prolonged dry season. Pelita Perkebunan, 33, $109-117$.

$* * 0 * *$ 